\title{
Leafy spurge effects on patterns of plant species richness
}

\author{
JACK L. BUTLER AND DANIEL R. COGAN
}

Authors are Research Ecologist, USDA Forest Service, Rocky Mountain Research Station, Rapid City, S.D. 57702 and Physical Scientist, US Bureau of Reclamation, Remote Sensing and Geographic Information Group, Denver Federal Center, Denver, Colo. 80228. At the time of the research JLB was Associate Professor, Department of Biology, University of South Dakota, and DRC was graduate research assistant, Department of Biology, University of South Dakota.

\section{Abstract}

The objective of this study was to simultaneously evaluate the impact of leafy spurge (Euphorbia esula L.) on plant species richness within and among a wide variety of vegetation types typical of the region. The study was conducted in Theodore Roosevelt National Park in southwestern North Dakota where 11 plant associations were identified as being particularly susceptible to invasion by leafy spurge. Representative infested and non-infested stands of the 11 associations were sampled using the protocol described by the National Vegetation Classification System. To evaluate the effects of leafy spurge infestation across a variety of vegetation types, the 11 associations were grouped into 1 of 4 general physiographic/vegetative units (floodplain, grassland, woodland, and shrubland). Species richness per sampled infested stand was reduced by an average of $51 \%(P \leq 0.05)$ in 7 of the 11 sampled associations. Total species richness in infested stands averaged $61 \%$ less than species richness within their non-infested counterparts for 10 of the 11 associations. Thirty species common to the majority of the associations were completely absent from infested stands and classified as sensitive, whereas 25 were minimally impacted and classified as persistent species. The overall effects of leafy spurge on species richness is complex and probably involves patterns of soil moisture, nutrient conditions, and disturbance that influence the abundance and distribution of all alien plants in Theodore Roosevelt National Park. However, because of the considerable redundancy in species distribution among a wide variety of plant associations and an aggressive control program, overall species richness does not appear to be threatened by infestations of leafy spurge at this time.

Key Words: landscape ecology, Theodore Roosevelt National Park, alien plants, National Vegetation Classification System, Northern Great Plains

Leafy spurge (Euphorbia esula L.) is one of the more serious rangeland invasive plants throughout much of the Northern Great Plains (Selleck et al. 1962, Lajeunesse et al. 1999, Masters and Sheley 2001). Common effects of leafy spurge infestations include decreases in frequency and gradual replacement of native species (Belcher and Wilson 1989), decreases in livestock carrying capacity (Lym and Kirby 1989), reductions in habitat use by native ungulates (Trammell and Butler 1995), and disruptions of

Authors wish to thank Jim Von Loh and Paula Andersen for assistance in data collection and Rudy King for assistance in statistical analysis. We thank Cheryl Schmidt, Dan Uresk, Lakhdar Benkobi, Jerry Dodd and three anonymous reviewers for reviewing early drafts of the manuscript.

Manuscript accepted 15 Aug. 02

\section{Resumen}

El objetivo de este estudio fue evaluar simultáneamente el impacto del "Leafy spurge" (Euphorbia esula L.) en la riqueza de especies de plantas dentro y entre una amplia variedad de tipos de vegetación típicos de la región. El estudio se condujo en el Parque Nacional Theodore Roosvelt en el sudoeste de North Dakota, donde 11 asociaciones vegetales se identificaron como particularmente susceptibles a la invasion de "Leafy spurge". Poblaciones representativas, infestadas y no infestadas, de las 11 asociaciones se muestrearon usando el protocolo descrito por el Sistema Nacional de Clasificación de Vegetación. Para evaluar los efectos de la infestación de "Leafy spurge" a través de una variedad de tipos de vegetación, las 11 asociaciones fueron agrupadas dentro de una de cuatro unidades generales fisiográficas/vegetativas (planicie inundable, zacatal, bosque y matorral). En 7 de las 11 asociaciones la riqueza de especies por población infestada muestreada se redujo en promedio $51 \%$ (P $\leq$ 0.05). La riqueza total de especies en las poblaciones infestadas promedio $61 \%$ menos que la riqueza de especies dentro de sus contrapartes no infestadas, esto en 10 de las 11 asociaciones. 30 especies, comunes en la mayoría de las asociaciones, estuvieron completamente ausentes en las poblaciones infestadas y se clasificaron como sensitivas, mientras que 25 fueron mínimamente impactadas y clasificadas como especies persistentes. El efecto general del "Leafy spurge" sobre la riqueza de especies es complejo y probablemente involucra patrones de humedad del suelo, condiciones de nutrientes y disturbio que influyen la abundancia y la distribución de especies invasoras del Parque Nacional Theodore Roosvelt. Sin embargo, debido a la considerable redundancia en la distribución de especies entre la amplia variedad de asociaciones de plantas y a un programa agresivo de control, en este tiempo, la riqueza general de especies de plantas no parece ser amenazada por las infestaciones de "Leafy spurge".

natural processes such as fire frequency, nutrient cycling, and forage production (Hein and Miller 1992). Past research has documented the impact of leafy spurge on species richness or dominance patterns in 1 or more localized community types. However, very little information is available that simultaneously addresses the effects of an aggressive exotic plant such as leafy spurge on plant species richness at a variety of spatial scales.

The relatively recent and well-documented invasion of leafy spurge into the South Unit of Theodore Roosevelt National Park, North Dakota provides an opportunity to investigate local and landscape level impacts of leafy spurge on native plant species richness. Anderson et al. (1996), using aerial photography and a 
geographic information system, reported that leafy spurge infested over 550 hectares or $3 \%$ of the South Unit of Theodore Roosevelt National Park. Further, a number of autecological and phytosociological studies were conducted in the Park prior to leafy spurge infestation, which provide an important historical perspective (Cogan 1999).

Our objectives were to compare species richness among a wide variety of plant associations infested with leafy spurge, simultaneously examine the effects of leafy spurge at broader spatial scales, and assess vulnerability of individual species to leafy spurge invasion. Species richness was selected as the response variable because it can be compared within and among a wide variety of vegetation types that may be differentially impacted by leafy spurge. Richness is also a concept that is fairly easy to convey to a wide variety of audiences. To reduce the chance of over-estimating the impact of leafy spurge, we elected to focus our evaluation on species that are relatively common within and among a wide range of plant associations in the region.

\section{Materials and Methods}

The study was conducted within the South Unit of Theodore Roosevelt National Park (hereafter referred to as the Park; $46^{\circ} 55^{\prime} \mathrm{N}, 103^{\circ} 31^{\prime} \mathrm{W}$ ) in southwestern North Dakota. The South Unit encompasses about 18,600 ha $(66 \%$ of Theodore Roosevelt National Park). The region contains various layers of soft substrates that have been continuously eroded by the Little Missouri River and its tributaries, leaving a heavily dissected landscape consisting of a complex mixture of deep valleys, rugged ravines, and gently rolling uplands that typify "badlands" type topography (Gauger et al. 1930).

The climate is continental with long, cold winters $\left(-12.6^{\circ} \mathrm{C}\right.$ long-term low average) and short, warm summers $\left(22^{\circ} \mathrm{C}\right.$ long-term high average). Seventy-five percent of the annual total precipitation of $360 \mathrm{~mm}$ occurs between April and September with June being the wettest month (Lee 1983). The vegetation of the Park is primarily composed of mixedgrass prairie species typical of much of the northern Great Plains (Whitman 1979). Shrubs occur on slightly more mesic sites with trees confined to areas with relatively high soil moisture such as floodplains, north-facing slopes, and dissected drainages (Hansen et al. 1984, Girard 1985, Hirsch 1985).
Our investigation was conducted in conjunction with the USGS-NPS National Park Vegetation Mapping Program (maps available online [http://www.nps.gov/gis/ park gisdata/ndakota/thro.htm]) for the Park (Von Loh et al. 2000). Classification of the vegetation in the Park began in 1997 and followed procedures described by the National Vegetation Classification System (NVCS; Grossman et al. 1998). The NVCS uses gradient directed transects (gradsects; Gillison \& Brewer 1985) and standard Relevé plot methodology (Knapp 1984) to determine species composition and foliar cover for all woodland, shrubland, and herbaceous associations in THRO, or alliances if the community cannot be classified to the association level. Associations are the finest level of the NVCS and are identified based on plant communities that occur in uniform habitats, have a consistent physiognomy, and have a definitive floristic composition (Grossman et al. 1998). Alliances share 1 or more diagnostic species and are used by the NVCS to describe vegetation types at the level just above association. During the vegetation mapping process, a total of 18 associations were selected for investigating the effects of leafy spurge on species richness within and among associations. Associations were initially placed into 1 of 2 broad categories (infested and non-infested) based upon our ability to find both infested and non-infested stands for a particular association. The term stand is used to describe a local example of an association. Infested stands could not be located for 7 associations, which were subsequently classified as Not Infested. Eleven associations were identified for which a comparable number of infested and non-infested stands could be found. Stands within these 11 infested associations were labeled as Non-Infested or Infested. Sampled Infested stands had at least $25 \%$ cover of leafy spurge in the plot (the majority of the stands had $>50 \%$ cover of leafy spurge), occurred on similar topographic and landscape positions as the Non-Infested stands belonging to the same association, and were sampled using the same protocol as described by the National Vegetation Classification System. Our goal was to sample Infested stands that differed from Non-Infested stands only in the presence of leafy spurge.

All sampling was conducted during a 3week period in July 1997 and done in relatively uniform stands of vegetation with consistent physical conditions as described by the National Vegetation Classification
System for that particular association. Association descriptions are available online (http://www.natureserve.org/explorer) and were reviewed prior to site selection. Once a sample site was located, a 10 by $10 \mathrm{~m}$ plot was subjectively placed in an area that appeared to best represent that entire grassland or shrubland stand. Larger 20 by $20 \mathrm{~m}$ plots were used in woodlands, as established by the National Vegetation Classification System, so that a broader range of the overstory canopy could be included. The minimum number of plots per association was set at 4 , the maximum number at 12 . All species occurring within the plot were recorded by strata (canopy, sub-canopy, tall shrub, short shrub, and herbaceous); however, only species recorded in the herbaceous stratum, which also included seedlings for trees and shrubs, were used for this study because of the previously documented impact of leafy spurge on this layer (Belcher and Wilson 1989, Trammell and Butler 1995). Sampled vegetation types were then matched to higher order plant alliances and then to plant associations previously documented for southwestern North Dakota by the NVCS (Grossman et al. 1998, Von Loh et al. 2000).

Wilcoxon Rank Sum tests (SAS Release $8.1,1999-2000$ ) were used to evaluate differences in plot richness between NonInfested and Infested stands of leafy spurge infested associations (Zar 1999). To measure the cumulative effects of leafy spurge infestation across multiple associations, the associations were grouped into lof 4 general physiographic/vegetative units (floodplain, grassland, woodland, and shrubland), which roughly conform to the Formation classification of the National Vegetation Classification System (Grossman et al.1998). Total species richness was then estimated for each physiographic unit by constructing a master species list using all of the species recorded in Non-Infested, Infested, and Not Infested stands. For physiographic units that contained 1 or more of the 7 Not Infested Associations, species were simultaneously added to both the Non-Infested and Infested totals. A similar procedure was used to examine the impact of leafy spurge on species richness for the entire South Unit.

To evaluate our ability to consistently sample the majority of the species within each association, we compared our species lists with lists constructed from phytosociological studies completed in the Park and the surrounding area prior to 1985 , or before major infestations of leafy spurge 
were repoyted (Hansen et al. 1984, Girard 1985, Hirsch 1985). A historical master species list for 10 of the 11 associations used in our study was created using species recorded in at least $25 \%$ of the previous studies (Cogan 1999). A similar species list was constructed from the National Vegetation Classification System associations by summarizing the plant species recorded on each sample plot free of leafy spurge [Non-Infested Stands], which was labeled current. Sørensen community coefficients were then calculated $(C C s=2 c / s 1+s 2$, where $c=$ species in common, $s 1, s 2=$ number of species in associations 1 and 2, respectively) (Brower et al. 1990). Coefficients between historical and current data sets ranged from 0.68 to 0.90 for the 10 associations evaluated (Mean $=0.75 \pm 0.06 \mathrm{SD}$ ), which appear to indicate that the National Vegetation Classification System methodology used for this study captured the majority of the species consistently found in each association.

Species recorded in the 11 sampled Non-Infested stands were grouped by their frequency of occurrence across the associations. Species with an association frequency of $\geq 45 \%$ (i.e. species that occurred in 5 or more associations) were classified as common; species with frequencies ranging from 20 to $44 \%$ were classed as occasional. Species classified as uncommon had a frequency of occurrence in the associations of $<20 \%$. Association frequency was highly correlated $(r=0.91)$ with plot frequency for the common and occasional species. In other words, species that were common across associations tended to be common within an association. The general response of the species to infestations of leafy spurge was then used to further subdivide these categories before final analysis. First, all common and occasional species that were present in the Non-Infested stands but completely absent in the Infested stands were classified as sensitive. The remaining common and occasional species that occurred in > $67 \%$ of the Infested stands were classified as persistent.

\section{Results}

With the Non-Infested green ash (Fraxinus pennsylvanica Marsh.) and Infested cottonwood (Populus deltoides Marsh.) woodland associations serving as exceptions, species richness tended to average about 50 to 55 species per Noninfested stand and 22 to 28 species per Infested stand with a sampling intensity of $\geq 8$ plots (Table 1). Infestations of leafy spurge significantly reduced plot species richness by an average of $51 \%( \pm 7.5 \mathrm{SD})$ in 7 of the 11 associations. The greatest losses in plot richness were recorded in the silver sagebrush (Artemisia cana Pursh.), creeping juniper (Juniperus horizontalis Moench), and prairie sandreed [Calamovilfa longifolia (Hook.) Scribn.] associations whereas the sandbar willow (Salix exigua Nutt.), western snowberry (Symphoricarpos occidentalis Hook.), and green ash woodland associations were impacted the least $(P>0.05)$.

All 5 of the associations in the floodplain vegetation unit and 3 of the 4 grass-

Table 1. Number of species present only in non-infested (NI) stands or infested (INF) stands, or present in both NI and INF stands by association (abbreviation in parenthesis), physiographic unit, and for the entire South Unit of Theodore Roosevelt National Park; and mean richness per stand $( \pm \mathrm{SE}, \mathrm{n}=$ number of sampled stands) for 18 plant associations. Total richness for each association can be calculated by adding the value in the Both column to the respective value in the NI or INF column. Data were collected during the 1997 field season. Association names (by dominant species only) provided by Von Loh et al. (2000).

\begin{tabular}{|c|c|c|c|c|c|}
\hline \multirow[b]{2}{*}{ Physiographic Unit/Association } & \multicolumn{3}{|c|}{ Number of Species } & \multicolumn{2}{|c|}{ Mean Richness/Stand ${ }^{2}$} \\
\hline & $\overline{\mathrm{NI}}$ & $\mathrm{INF}^{2}$ & Both & NI & INF \\
\hline \multicolumn{6}{|l|}{ Floodplain } \\
\hline Salix exigua (Saex) & 31 & 1 & 13 & $11.1( \pm 1.2, n=7)$ & $11.8( \pm 1.2, n=5)$ \\
\hline Fraxinus pennsylvanica (Frpe/F) & 31 & 1 & 8 & $16.3( \pm 2.6, n=4)$ & $7.7( \pm 0.9, n=3)^{*}$ \\
\hline Populus deltoides (Pode) & 14 & 25 & 36 & $17.6( \pm 1.7, n=8)$ & $16.6( \pm 2.2, n=11)$ \\
\hline Artemisia cana (Arca) & 31 & 8 & 31 & $16.3( \pm 1.7, n=8)$ & $7.6( \pm 0.7, n=11)^{*}$ \\
\hline Symphoricarpos occidentalis (Syoc) & $\underline{32}$ & $\underline{6}$ & 20 & $12.7( \pm 1.8, n=9)$ & $10.3( \pm 1.4, n=9)$ \\
\hline Total & 49 & 16 & 69 & & \\
\hline \multicolumn{6}{|l|}{ Grassland } \\
\hline Schizachryium scoparium (Scsc) & 54 & & & & \\
\hline Calamovilfa longifolia (Calo) & 41 & 2 & 11 & $21.2( \pm 3.4, n=5)$ & $8.5( \pm 1.6, n=4)^{*}$ \\
\hline Pascopyrum smithii (Pasm) & 45 & 7 & 17 & $18.0( \pm 1.3, n=10)$ & $9.8( \pm 1.2, n=7)^{*}$ \\
\hline Stipa comata (Stco) & $\underline{42}$ & $\underline{4}$ & 18 & $21.3( \pm 1.4, n=12)$ & $12.4( \pm 1.0, n=9)^{*}$ \\
\hline Total & $\overline{43}$ & 5 & 62 & & \\
\hline \multicolumn{6}{|l|}{ Woodland } \\
\hline Populus tremuloides (Potr) & 56 & & & & \\
\hline Fraxinus pennsylvanica (Frpe/W) & 68 & 7 & 40 & $22.0( \pm 4.0, n=9)$ & $20.9( \pm 4.2, n=8)$ \\
\hline Juniperus scopulorum (Jusc) & $\underline{49}$ & $\underline{6}$ & 20 & $23.4( \pm 1.9, n=9)$ & $13.4( \pm 0.9, n=5)^{*}$ \\
\hline Total & 52 & 7 & 72 & & \\
\hline \multicolumn{6}{|l|}{ Shrubland } \\
\hline Sarcobatus vermiculatus (Save) & 26 & & & & \\
\hline Shepherdia argentea (Shar) & 57 & & & & \\
\hline Chrysothamnus nauseosus (Chna) & 33 & & & & \\
\hline Juniperus horizontalis (Juho) & 51 & 2 & 24 & $31.8( \pm 1.2, n=8)$ & $13.0( \pm 1.3, n=5)^{*}$ \\
\hline Rhus trilobata (Rhtr) & 51 & & & & \\
\hline Artemisia tridentata (Artr) & 64 & & & & \\
\hline Total & 13 & 2 & 118 & & \\
\hline South Unit & 50 & 5 & 166 & & \\
\hline
\end{tabular}

Richness between non-infested and infested stands within an association were compared using a Wilcoxon Rank Sum Test ( $*=P \leq 0.05$ ).

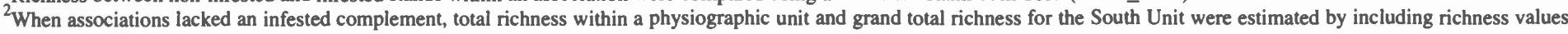
from Not Infested stands. 
land associations sampled had stands infested with leafy spurge (Table 1). Similarly, 2 of the 3 woodland associations were infested. In contrast, only 1 shrubland association was infested with leafy spurge during the 1997 field season. The end result was $28 \%$ to $36 \%$ fewer species on the Infested plus Not Infested master species list within the floodplain, grassland, and woodland vegetation units compared to the Non-infested plus Not Infested master species list. Because only 1 shrub association was infested, shrublands as a physiographic unit were minimally impacted by infestations of leafy spurge. The cumulative effect of leafy spurge infestations for the entire South Unit was $21 \%$ fewer species contributing to grand total richness.

The majority ( 77 to $93 \%$ ) of the species recorded in Infested stands were also observed in Non-Infested stands (Table 1). In contrast, 50 to $79 \%$ of the species recorded within individual Non-Infested stands were absent from Infested stands. When considered collectively across all 11 associations, 93 species found in the NonInfested stands were not recorded in any of the Infested stands (Table 2). One-third of these species were classified as either occasional or common, and were subsequently identified as sensitive species. Association frequencies for 42 of the 67 common and occasional species recorded in both Non-Infested and Infested stands were partially impacted by leafy spurge infestations (association frequencies reduced 33 to $99 \%$ ). The remaining 25 species were considered to be minimally impacted (association frequency reduced $<$ $33 \%$ ) and were subsequently classified as persistent species.

Forbs, graminoids, and shrubs/subshrubs respectively composed $53 \%, 25 \%$, and $21 \%$ of the 98 species classified as occasional and common within the 11 Non-Infested associations (data not shown). However, of the 30 sensitive species that were completely absent from leafy spurge infested stands, $70 \%, 7 \%$, and $20 \%$ were forbs, graminoids, and shrubs/subshrubs, respectively (Table 3). The majority (>50\%) of the common and occasional species present in Non-Infested stands but missing from Infested stands were concentrated in the needle-andthread (Stipa comata Trin. \& Rupr.) and prairie sandreed grassland associations, and the creeping juniper shrubland association (Table 3). The green ash woodland association contained the largest number of the 30 common and occasional species; however, most occurred at relatively low frequencies. One nonvascular plant, club moss (Selaginella densa Rydb.), was conspicuously absent in the Infested stands. Two species of forbs, field bindweed (Convolvulus arvensis L.) and Canada thistle (Cirsium arvense L. \& Scop.), are non-native to the Park. Carrion-flower (Smilax herbacea L.) was the only sensitive species not represented in any of the sampled Not Infested associations.

The 25 persistent species were fairly evenly distributed among the assigned growth forms of forbs $(36 \%)$, graminoids (36\%), and shrubs/subshrubs $(28 \%)$ (Table 4). Association frequencies for 5 of these persistent species, threadleaf sedge (Carex filifolia Nutt.), fringed sagewort (Artemisia frigida Nutt.), smooth brome (Bromus inermis Leyss.), red false globemallow [Sphaeralcea coccinea (Pursh) Rydb.] and porcupine-grass (Stipa spartea Trin.), were identical between NonInfested and Infested stands, whereas association frequencies for 3 additional persistent species [western wild rose, Rosa woodsii Lindl.; quackgrass, Agropyron repens (L.) Beauv.; and buffalo currant, Ribes odoratum Wendl.) were higher in Infested stands. Persistent species considered non-native to the Park include Kentucky bluegrass (Poa pratensis L.), goat's beard (Tragopogon dubius Scop.), yellow sweet clover [Melilotus officinalis (L.) Pall.], white sweet clover (M. alba Medic), smooth brome, and quackgrass.

\section{Discussion}

Established infestations of leafy spurge can dominate and displace native species, creating homogeneous plant communities (Belcher and Wilson 1989, Lym and Kirby 1989, Trammell and Butler 1995). However, caution must be exercised when interpreting reductions in species richness in response to heavy infestations of alien plants within and among a variety of plant community types. Infrequent species may not be recorded in infested stands because the very nature of being rare. It is also quite possible to overlook infrequent species because they are often easily obscured by more common plants, especially in dense stands of leafy spurge. Sampling intensity also plays a major role in detecting infrequent species. Therefore, we concentrated much of our analyses on species that were historically common (Cogan 1999) and occurred with sufficient frequency among the 11 non-infested associations, which was arbitrarily set at $\geq$ 3 associations. These species were further classified as being either sensitive (completely absent in infested stands) or persistent to infestations of leafy spurge. Using these criteria, we identified 30 sensitive and 25 persistent species for detailed analysis.

We found a strong correlation between association frequency for these 55 species and their respective plot frequencies, which indicated that they were common both within and among associations. This is not unusual considering that several of the plant associations in THRO lack a discernible separation or ecotone (Von Loh et al. 2000). Further, many species in badlands type topography may have a greater affinity for specific soil and topographic characteristics that are repeated across the landscape (Butler et al. 1986) than for a particular vegetation type.

Whether evaluating total species richness or plot species richness, the overall pattern of reduction in richness in response to infestations of leafy spurge appears to be relatively consistent among the 7 associations significantly impacted by infestations of leafy spurge. The observed reductions in species richness are likely the result of a combination of not detecting the infrequent species, which accounted for about half of the species, and a partial reduction $(34 \%$ of the species) or complete elimination (15\% of the species) of the occasional and common species. Three of the 4 associations that proved to be exceptions to this trend are primarily found within the floodplain of the Little Missouri River.

Table 2. Number of species by association frequency class (frequency of occurrence in non-infested associations) and percent difference in association frequency (expressed as a percent reduction in association frequency) between non-infested (NI) and infested (INF) stands evaluated during the 1997 field season in the South Unit of Theodore Roosevelt National Park, N.D.

\begin{tabular}{lccccc}
\hline \hline & \multicolumn{5}{c}{ Percent Reduction in Frequency Between } \\
\cline { 2 - 6 } NI and INF Stands & \\
\cline { 2 - 6 } Frequency Class & $100 \%$ & $67<100 \%$ & $33-66 \%$ & $<33 \%$ & Totals \\
\hline Infrequent $(9-19 \%)$ & 63 & 0 & 9 & 27 & 99 \\
Occasional $(20-44 \%)$ & 18 & 9 & 9 & 5 & 41 \\
Common $(\geq 45 \%)$ & $\underline{12}$ & $\underline{7}$ & $\underline{17}$ & $\underline{20}$ & 56 \\
$\quad$ Totals & 93 & 16 & 35 & 52 & 196 \\
\hline
\end{tabular}




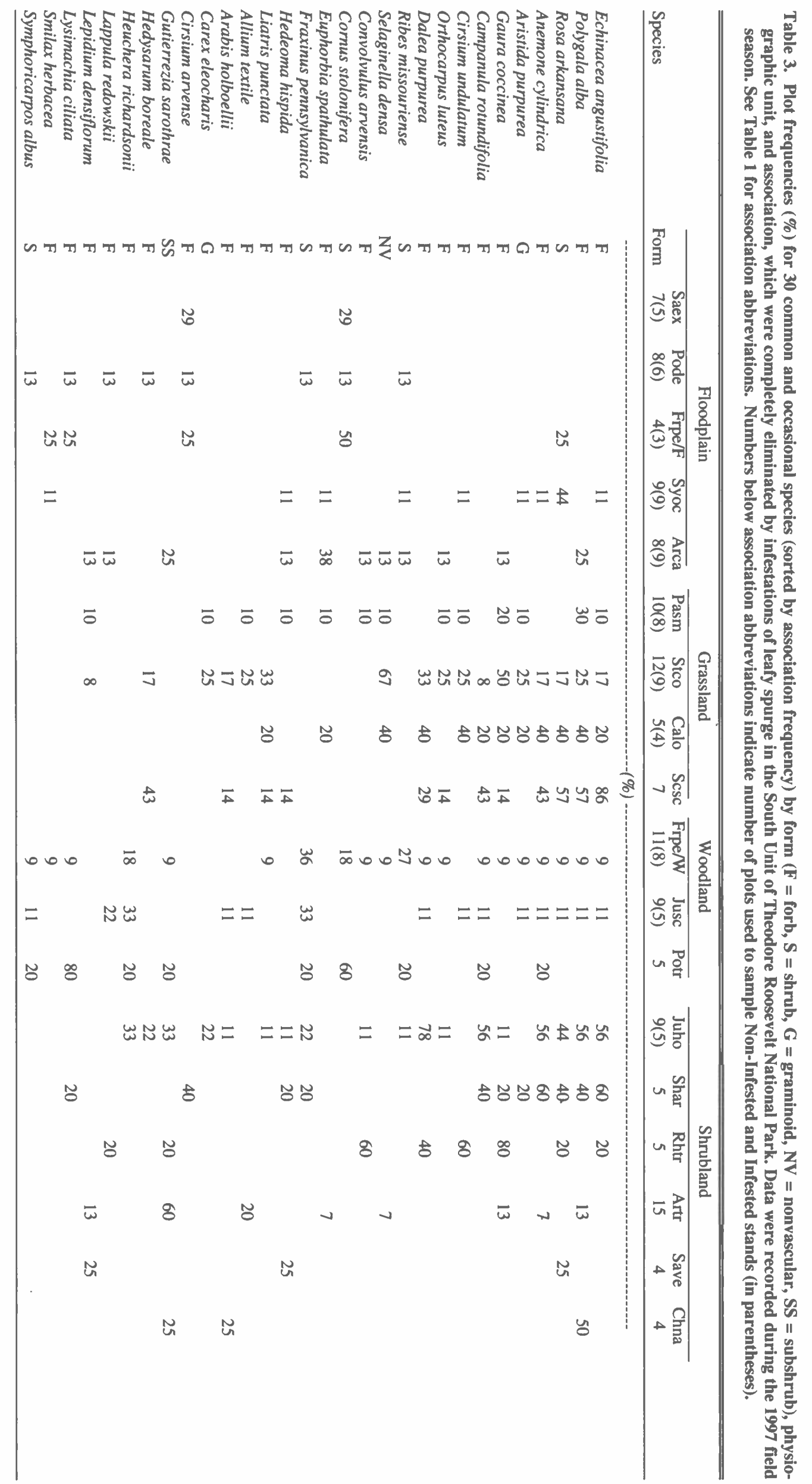


Table 4. List of common and occasional species recorded during the 1997 field season in the South Unit of Theodore Roosevelt National Park, North Dakota by form $(F=$ forb, $S=$ shrub, $G=$ graminoid, NV = nonvascular, SS = subshrub), number of Non-infested (NI) associations, number of infested (INF) stands, and percent difference between NI and INF stands.

\begin{tabular}{|c|c|c|c|c|}
\hline Species & Form & NI Assoc. & $\begin{array}{c}\text { INF } \\
\text { Stands }\end{array}$ & $\begin{array}{c}\% \\
\text { Difference }\end{array}$ \\
\hline Symphoricarpos occidentalis & S & 11 & 10 & -9 \\
\hline Pascopyrum smithii & G & 11 & 8 & -27 \\
\hline Artemisia cana & $S$ & 10 & 9 & -10 \\
\hline Poa pratensis & G & 10 & 8 & -20 \\
\hline Lactuca oblongifolia & $\mathrm{F}$ & 10 & 7 & -30 \\
\hline Calamovilfa longifolia & G & 10 & 7 & -30 \\
\hline Tragopogon dubius & F & 9 & 8 & -11 \\
\hline Melilotus officinalis & $\mathbf{F}$ & 9 & 7 & -22 \\
\hline Achillea millefolium & F & 8 & 7 & -13 \\
\hline Vicia americana & $\mathrm{S}$ & 8 & 7 & -13 \\
\hline Nassella viridula & G & 8 & 6 & -25 \\
\hline Hesperostipa comata & G & 8 & 6 & -25 \\
\hline Carex filifolia & G & 7 & 7 & 0 \\
\hline Artemisia frigida & SS & 7 & 7 & 0 \\
\hline Galium boreale & F & 7 & 5 & -29 \\
\hline Rhus trilobata & $\mathrm{S}$ & 7 & 5 & -29 \\
\hline Rosa woodsii & $\mathbf{S}$ & 6 & 7 & +17 \\
\hline Bromus inermis & G & 6 & 6 & 0 \\
\hline Sphaeralcea coccinea & F & 5 & 5 & 0 \\
\hline Ambrosia psilostachya & $\mathrm{F}$ & 5 & 4 & -20 \\
\hline Lygodesmia juncea & F & 4 & 3 & -25 \\
\hline Melilotus alba & F & 4 & 3 & -25 \\
\hline Elymus repens & G & 3 & 5 & +67 \\
\hline Ribes odoratum & S & 3 & 5 & +67 \\
\hline Hesperostipa spartea & G & 3 & 3 & 0 \\
\hline
\end{tabular}

Leafy spurge, because of its extensive root system and habit of forming a closed canopy, is well recognized for having wide ecological amplitude and broad competitive effects on local species distribution and abundance (Selleck et al. 1962). However, changes in composition appear to go beyond simple reductions in species richness to possibly more complex alterations of community structure (Woods 1997). In our study, forbs appear to be over represented in the sensitive species group, compared to their representation in the Non-Infested stands, while under represented in the persistent species group. Similarly, graminoids appear to be somewhat better represented in the persistent group compared to the sensitive group. Annual species are also less common in the persistent group.

Competition among species that are taxonomically and ecologically similar may partially explain some of these alterations in community structure. However, it appears that the overall effects of leafy spurge on community assemblages may be more complex and involve patterns of soil moisture, nutrient conditions (PlantyTabacchi et al. 1996, Stohlgren et al. 1998), and disturbance in relation to the distribution of leafy spurge and other alien plant species in the Park (Larson et al. 2001). Associations within the floodplain contain a number of persistent species,
Park in addition to several picnic areas, and a concession that provides horses for trail rides. Numerous hiking/horseback trails also occur along the floodplain and several major drainages. Several large prairie dog towns are found along the upper terraces of the floodplain (Von Loh et al. 2000) and grazing by bison tends to be higher on the relatively flat landscape of the floodplain (Norland 1984).

The chronological sequence of leafy spurge invasion into the Park may have initially occurred within the mesic and disturbed floodplain, spreading into the upland drainages and draws, and finally up into the upland grasslands and shrublands (Anderson et al. 1996). Consequently, the floodplain likely represents the most mature stands of leafy spurge and assemblages of alien plants in the Park. Indeed, the cottonwood association probably contains the highest proportion of alien species in the Park (Larson et al. 2001). This pattern of alien plant invasion provides insight into the relationship between the number of sensitive species and the percent of the flora composed of persistent species. Many of the species we identified as sensitive to infestations of leafy spurge are undoubtedly sensitive to other aliens as well. Consequently, leafy spurge and other alien species, with their long history within the floodplain associations, appear to have a strong filtering effect on sensitive species resulting in a higher percentage of the flora characterized by persistent species. The differences in richness between Non-Infested and Infested floodplain stands is therefore probably largely the result of not recording infrequent species, either because they were actually displaced by leafy spurge and other alien species, or were simply overlooked because of the extreme dominance of leafy spurge. In contrast, the drier and less disturbed associations outside of the floodplain have a shorter history of alien plant infestations and are characterized by the loss of a higher number of common, sensitive species.

Although species richness among many of the sample stands has been significantly reduced by infestations of leafy spurge, overall richness in the Park as a whole is not particularly threatened at this time for several reasons. First, leafy spurge infestations cover only about $3 \%$ of the area in the South Unit (Anderson et al. 1996). Second, redundancy in the distribution of many species among the associations, including the Not Infested associations, is relatively high. This is especially true for the common, sensitive species that are 
perennials. Third, the majority of the associations are repeated numerous times across the badlands landscape, which enhances species redundancy (Von Loh et al. 2000). Finally, the Park has implemented an aggressive integrated control program, which appears to be fairly successful in halting, and possibly reversing, the spread of leafy spurge in the Park (Paula Andersen, personal communication). However, native species richness within the floodplain associations may be particularly vulnerable to infestations of leafy spurge and other alien species. Long-term analyses of these associations may indicate future assemblages with low species richness characterized by a relatively few persistent native species and a larger number of alien species. Ultimately, the floodplain associations may serve as major sources of alien plants for the upland associations (Stohlgren et al. 1998).

\section{Literature Cited}

Anderson, G.L., J.H. Everitt, D.E. Escobar, N.R. Spencer, and R. J. Andrascik. 1996. Mapping leafy spurge (Euphorbia esula) infestations using aerial photography and geographic information systems. Geocarto Int. 11:81-89.

Belcher, J.W. and S.D. Wilson. 1989. Leafy spurge and the species composition of a mixed-grass prairie. J. Range Manage. 42: 172-175.

Brower, J.E., J. Zar, and C.N. von Ende. 1990. Field and Laboratory Methods for General Ecology. Wm. C. Brown. Dubuque, lowa.

Butler, J.L., H.L. Goetz, and J.L. Richardson. 1986. Vegetation and soil-landscape relationships in the North Dakota Badlands. Amer. Midl. Natur. 116:378-386.

Cogan, D.R. 1999. Effects of leafy spurge (Euphorbia esula L.) on plant species diversity in Theodore Roosevelt National Park. M.A. Thesis, Univ. of South Dakota. Vermillion, S.D.

Gauger, A.W., A.C. Leonard, E.F. Chandler, H.E. Simpson, and W.E. Budge. 1930. Geology and natural resources of North Dakota. Univ.of North Dakota Dept. Bull. 11. Grand Forks, N.D.

Gillison, A.N. and K.R.W. Brewer. 1985. The use of gradient directed transects or gradsects in natural resource survey. J. Environ. Manage. 20:103-127.

Girard, M.M. 1985. Native woodland ecology and habitat type classification of Southwestern North Dakota. Ph.D. Thesis. North Dakota State Univ. Fargo, N.D.

Great Plains Flora Association. 1986. Flora of the Great Plains. Univ. Press of Kansas, Lawrence, Kans.
Grossman, D.H. D. Faber-Langendoen, A.w. Weakley, M. Andeerson, P. Bourgeron, R. Crawford, K. Goodin, S. Landaal, K. Metzler, K.D. Patterson, M. Pyne, M. Reid, and L. Sneddon. 1998. International classification of ecological communities: terrestrial vegetation of the United States. Volume I: The National Vegetation Classification Standard. The Nature Conservancy, Arlington, Virg.

Hansen, P.L., G.R. Hoffman, and A.J. Bjugstad. 1984. The vegetation of Theodore Roosevelt National Park, North Dakota: A habitat type classification. USDA, Forest Service Gen. Tech. Rep. RM-113. Rapid City, S. D.

Hein, D.G. and S.D. Miller. 1992. Influence of leafy spurge on forage utilization by cattle. J. Range Manage. 45:405-407.

Hirsch, K.J. 1985. Habitat type classification of grasslands and shrublands of southwestern North Dakota. Ph.D. Thesis. North Dakota State Univ. Fargo, N.D.

Knapp, R. 1984. Sample relevé areas (distribution, homogeneity, size, shape) and plot-less sampling. P. 100-119. In: R. Knapp, (ed.) Sampling methods and taxon analysis in vegetation science. Dr. W. Junk Publishers, The Hague.

Lajeunesse, S., R. Sheley, C. Duncan, and R. Lym. 1999. Leafy Spurge, p. 249-260. In: R. L. Sheley and J.K. Petroff (eds.) Biology and management of noxious rangeland weeds. Oregon State Univ. Press, Corvallis, Ore.

Larson, D.L. P.J. Anderson, and W. Newton. 2001. Alien plant invasion in mixed-grass prairie: effects of vegetation type and anthropogenic disturbance. Ecol. Appls. 11:128-141.

Lee, P. H. 1983. Terrain, climate, and vegetation in the badlands of the Little Missouri River in North Dakota. M.S. Thesis. Univ. North Dakota. Grand Forks, N.D.

Lym R.G. amd D.R. Kirby. 1989. Cattle foraging behavior in leafy spurge (Euphorbia esula) infested rangeland. Weed Tech. 1:314-318.

Masters, R.A. and R.L. Sheley. 2001. Principles and practices of managing rangeland invasive plants. J. Range Manage. 54:502-517.

Norland, J.E. 1984. Habitat use and distribution of bison in Theodore Roosevelt National Park. M.S. Thesis. Montana State Univ. Bozeman, Mont.

Planty-Tabacchi, A., E. Tabacchi, R.J. Naiman, C. DeFerrari, and H. DeCamps. 1996. Invasibility of species-rich communities in riparian zones. Conserv. Biol. 10:598-607.

SAS Release 8.1. 1999-2000. SAS Institute Inc. Cary, N.C.

Selleck, G.W., R.T. Coupland, and C. Frankton. 1962. Leafy spurge in Saskatchewan. Ecol. Monogr. 32:1-29.

Stohlgren, T.J., K.A. Bull, Y. Otsuki, C.A. Villa, and M. Lee. 1998. Riparian zones as havens for exotic plant species in the central grasslands. Plant Ecol. 138:113-125.
Trammell, M.A. 1994. Exotic plants of Theodore Roosevelt National Park: extent, distribution, and ecological impact. M.A. Thesis, Univ. of South Dakota. Vermillion, S.D.

Trammell, M.A. and J.L. Butler. 1995. Effects of exotic plants on native ungulate use of habitat. J. Wildl. Mange. 59:808-815.

Von Loh, J., D. Cogan, J. Butler, D. FaberLangendoen, D. Crawford, and $M$. Pucherelli. 2000. National Park Service Vegetation Mapping Program: Theodore Roosevelt National Park. U.S. Dept. of the Interior, Bur. Reclamation Tech. Memorandum No. 8260-00-04. Tech. Service Center, Denver, Colo.

Whitman, W.D. 1979. Analysis of grassland vegetation on selected key areas in southwestern North Dakota. Regional Environmental Assessment Program (REAP). Project No.79-14. North Dakota State Univ. Fargo, N.D.

Woods, K. D. 1997. Community response to plant invasion, p. 56-68. In: J.O. Luken and J.W. Thieret (eds.) Assessment and management of plant invasions. Springer-Verlag, New York Inc., N.Y.

Zar, J.H. 1999. Biostatistical Analysis, fourth edition. Prentice-Hall, Inc., Upper Saddle River, N.J. 